\title{
Assessing the Transparency Practices in Public Bidding of Philippine Rice Research Institute in the Philippines
}

\author{
Angemil Mayette F. Magtalas $1,2 \quad$ Marc Jon S. Flores ${ }^{2}$ Rocido D. Domingo ${ }^{2}$ \\ Christopher Dave B. Musa ${ }^{1} \quad$ Vilma B. Ramos ${ }^{2}$ \\ 1.Philippine Rice Research Institute Science City of Munoz, Nueva Ecija, Philippines \\ 2. Department of Public Administration, Nueva Ecija University of Science and Technology, Philippines
}

\begin{abstract}
The objective of this paper is to describe the observance of the principle of transparency in government procurement as required by Republic Act 9184 also known as Government Procurement Act (GPRA) of 2003. The measurement of observance is in the domains of the observance of procedures on public bidding, participation of stake holders in the bidding proceedings and public access to bidding information. The study used the descriptive qualitative method of research. Interview was held and Focus Group Discussion (FGD) was resorted to undertake member checking and triangulation of responses. Purposive sampling method was used to select participants to the study. The researcher interviewed 6 participants from the Procurement and Property Management Division-BAC (Bids and Awards Committee) Secretariat Unit of Philippine Rice Research Institute who are in- charge of public bidding activities of the institution. The study found that there is observance of transparency in the procurement process conducted by the agency and the information on the bidding activities are highly accessible and downloadable through the Philippine Government Electronic Procurement System (PhilGEPS) and agency official website. The standard process in the implementation of the procurement activities embodied in the Implementing Rules and Regulations of RA 9184 is strictly observed. It is recommended that the same evaluation be done in some other government entities to determine observance of policy on procurement in the government sector.
\end{abstract}

Keywords: Transparency, Government Procurement Public Bidding, RA9184, the Philippines, Public Administration

DOI: $10.7176 / \mathrm{PPAR} / 9-2-06$

\section{Introduction}

The study of Osborne and Gaebler (1993) provides the momentum for entrepreneurial government applying the corporate principles in government operations and inviting competent private sectors to provide public services done through competitive bidding. The legendary book entrepreneurial government introduced the idea of a public sector earning income while using public funds. That the sustainability of government operations rest on how it applies the private corporation principles in the management of public affairs. They started a movement in public management dominated by the ideas of efficiency, cost saving effectiveness, and managerial competencies as the key to government sustainability (Reyes, DR (1994). They pushed forward the idea that private sector is more efficient producer of public goods than the public sector. Alongside efficiency in operation in private sector is transparency in operation to encourage customers and stakeholders support long before it is practiced in government entity. Transparency is an important component of institutional operation whether local or national, private or public in nature. Its importance to government operations is globally recognized. Experiences of Local Government Units (LGUs) of the world would point to the fact that transparency embraces the principle of accountability. A principle developed in the public governance era where public official should answer for the outcome of his decision having negative or positive effects on the community. It is something which government and the organization must invest (Gabriel, 2017), considering its prime importance to prevent negative bureaucratic behaviors including graft and corruption (Benito,2016); bureaucratic red tape in the processing of government transactions and operations (Gabriel,2018) and other practices which put hindrance to the effective and efficient delivery of services to the people. In the performance of functions in the local government level, transparency is found to have strong link to legislative performance and must be observed not only in theory but also in actual adherence (Gabriel and Gutierrez, 2017, Gabriel and Ong, 2018). Observance of transparency is believed to create higher level of government accountability which in turn imposes upon government entities and personnel alike to adhere to Code and Conduct and Ethical Standards for Public Officials and Employees (Bernas, JG. 1996). According to Ingrams (2017) 'transparency is the principle and practice that enables organization, insiders and outsiders to obtain accurate information about organizational activities". Transparency may be categorized as passive or active. When it involves mere dissemination of information without the intention of encouraging reaction, it can be considered as passive while active transparency happens when the information serves as a tool for policy effectiveness requiring actions which citizens could provide. In international context, "transparency relates to the accurate mode of assessing the openness, accessibility and value of government and monitors the internal workings or performance of an 
organization having impact on the social, political and economic realities of the community. Transparency is a critical matter to open up of government and governance to inform scrutiny and participation. Transparency encourages civic engagement and improved level of efficiency (Orelli, 2017). It is an effective deterrent to corruption in public procurement (OECD, 2006).

The governing principles in government procurement in the Philippines are embodied in RA 9184. One of these principles is transparency in the procurement process and in the implementation of procurement contracts (RA 9184). Procurement is considered as one of the prominent works of the government considering that billions of public funds are spent every year to purchase goods, services and even infrastructures necessary to perform their duties and deliver services to its citizens. In many countries, including the Philippines, the government is one of the leading procuring entities. According to the Senate Economic Planning Office, several studies in the past referred to the Philippine public procurement system as a spawning ground for official corruption. By government's own estimates, as much as $\mathrm{Ph} 22$ billion is lost each year in government spending due to corruption in procurement. Realizing the severity of the situation, a reform process was initiated, which resulted in the enactment of Republic Act No. 9184 otherwise known as the Government Procurement Act (GPRA) of 2003.

The strict observance of transparency in public is a critical matter. This is because the method in which the administration accomplishes its transactions directly affects the public view on the government. Moreover, it aims to encourage the people's good will and to strengthen public trust. It results to more practical benefits in the business industry such as increased competition and better value for goods and services. The law also serves as a tool to rebuild trust and confidence of the people to public institution (Brillantes and Hernandez, 2011).

The standardization of procurement processes, including the availability and easy access to information that is simple to understand make doing business transactions with the government much more interesting to the suppliers' community.

The Philippine government through Republic Act No. 9184, otherwise known as "Government Procurement Reform Acts", was created and established through the procurement guidelines and Implementing Rules and Regulations under the said law. It promotes transparency in procurement, in which citizens have access to government transactions (such as opportunities, awards and disbursements) through the use of the Philippine Government Electronic Procurement System (PhilGEPS). The public can now monitor if the government is using the public funds wisely in the purchase of goods and services. The PhilGEPS also promotes competitiveness and standardized procurement process throughout the whole government system.

According to its 2016 Revised Implementing Rules and Regulations (IRR), Rule IV, Section 10, "all procurement of the government shall undergo competitive bidding". Public Bidding or Competitive Bidding is the manner in which the procuring entity issues a public bid with the intention of getting the best offer from competing companies. This process is required by Law to every government agency that issues a bid. It creates a transparent setting that is open and fair. This basically means that any company, regardless of its size, annual revenue or other factors, will be welcomed to the bidding process and will be given a fair chance as the rest of the competition as long as they comply with all the requirements provided in the IRR. However, despite the enactment of the Procurement Act many are still in doubts as to the transactions in relation to procurement in government services. Many have entertained negative views on the process even without adequate evidence. Therefore, to check the theory against the practice and observance in the actual public setting, the study is done. The Philippine Rice Research Institute is a Government Owned and Controlled Corporation. It is an attached agency of the Department of Agriculture which leads the country's research and development for the benefit of the Filipino Rice Farmers. Its mission is to improve the level of competitiveness of every farmer and the Philippine Rice Industry in the world market and transforms it to become more profitable, resilient, and sustainable through responsive, balanced, environmentally sound, and partnership-based research, development and extension. The institute envisions a rice secure Philippines. This means a safe and nutritious rice supply that is accessible, affordable, and available at all times. The PhilRice transparency in its procurement activities is essential in promoting credibility to suppliers and being able to deliver the necessity of each project in order to achieve the Institute's mission and vision.

\subsection{Objectives of the Study}

Generally, the study was intended to identify the transparency dimension of Public Bidding process at Philippine Rice Research Institute.

Specifically, the study aimed at:

a) Describing the observance of procedures on public bidding,

b) Identifying the entities who are allowed to participate in their public bidding process and their limitations during the process;

c) Describing the documents related to public bidding that are accessible to the public.

This study covers the public bidding process of the Philippine Rice and Research Institute in Munoz City, Nueva Ecija, Philippines. The study is guided by the theoretical framework embodied in Republic Act 9184. 


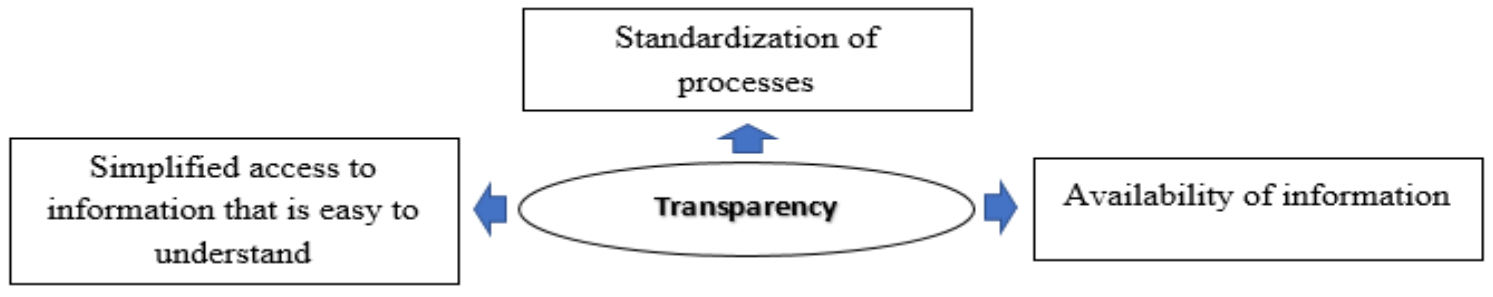

Figure 1. Research Paradigm

The study dealt with the academic challenge of describing the observance of transparency in the public procurement process of the Philippine Rice Research Institute, in Munoz City, in the Philippines. As the paradigm shows the observance shall be determined in the areas of access to information, presence of bids and awards committee members in actual Bid proceedings and the compliance to the provisions of the Act pertaining to standardization of procedure. The entire paradigm will provide information and insights on how transparency is observed in the subject agency.

According to Section 2 of the 2016 Revised Implementing Rules and Regulations of Republic Act No. 9184, otherwise known as, the Government Procurement Reform Act, the provisions of this IRR are in line with the commitment of the Government of the Philippines to promote good governance and its effort to adhere to the principles of transparency, accountability, equity, efficiency, and economy in its procurement process. It is the policy of the Government of the Philippines that procurement of Goods, Infrastructure Projects and Consulting Services shall be competitive and transparent, and therefore shall undergo competitive bidding, except as provided in Rule XVI of the IRR.

Transparency in the procurement process and in the implementation of procurement contracts through wide dissemination of bid opportunities and participation of pertinent non-government organizations.

Under Section 6.1 of the 2016 Revised IRR of RA9184 to systematize the procurement process, avoid confusion and ensure transparency, the GPPB shall pursue the development and approval of generic procurement manuals, standard Bidding Documents, and forms, including those to be used for major procurement like drugs and textbooks.

In addition, to promote transparency and efficiency, information and communications technology shall be utilized in the conduct of procurement procedures. Accordingly, there shall be a single portal that shall serve as the primary source of information on all government procurement. The PhilGEPS shall serve as the primary and definitive source of information on government procurement Sec. 8.1.1 of the IRR.

On Section 13.1 of the IRR states that to enhance the transparency of the process, the BAC shall, during the eligibility checking, short listing, pre-bid conference, preliminary examination of bids, bid evaluation, and postqualification, invite, in addition to the representative of the COA, at least two (2) observers who shall sit in its proceedings although they shall not be given the right to vote. While Sec. 25.7 states that, to ensure transparency and accurate representation of the bid submission, the BAC Secretariat shall notify in writing all bidders whose bids it has received through its PhilGEPS-registered physical address or official e-mail address. The notice shall be issued within seven (7) calendar days from the date of the bid opening.

According to Therese Ballard (2017), Director of the Procurement and Supply Chain Practice Group at UNOPS (the United Nations Office for Project Services), transparency in procurement takes form in a variety of practices, such as: publishing procurement policies; advance publication of procurement plans; advertisement of tender notices; disclosure of evaluation criteria in solicitation documents; publication of contract awards and prices paid; establishing appropriate and timely complaint/ protest/dispute mechanisms; implementing financial and conflict of interest disclosure requirements for public procurement officials; and publishing supplier sanction lists.

\section{Methodology}

\subsection{Research Method and Design}

This study used descriptive method of research. The questionnaire that serves as interview guide for gathering of data is provided by the researcher.

This study seeks to describe the prevailing practices of a government institution such as Philippine Rice Research Institute in imposing transparency in their public bidding activities; the transparency practices on public bidding process, how do they disseminate invitations and information to their stakeholders, who are the major players and their roles in every public bidding process, and what are the documents available to the public.

Homogeneous sampling was used in this research. It is a purposive sampling technique that aims to achieve a homogeneous sample whose units share similar characteristics or traits such as gender, background, occupation. The researcher chose this sampling method to answer research the questions that are specific to the 
characteristics of the group of interest.

For this study, the Researcher selected six (6) respondents from the Procurement and Property Management Division- BAC Secretariat Unit of Philippine Rice Research Institute. The respondents consist of the Head of the PPMD who also acts as the BAC Secretariat for Goods and Civil Works, the Head of the BAC Secretariat Unit who has been serving as the BAC Secretariat of the Institution for 15 years, and Administrative Assistants who have been assisting and facilitating the procurement process of Public Bidding of PhilRice transactions.

Focus Group Discussion was also conducted by the researcher to triangulate answers to the questionnaires and unstructured interview as well as to undertake member checking of responses. Through this process, the Researcher was able to have access to comparisons that was made by the participants based on their experiences.

\section{Results and Discussion}

According to Von Lucke and Geiger (2010), creation of open government rest on the willingness of the government to provide free and open access to data, information, knowledge and sources. However, they also cited that not all requests for information are favorably endorsed especially when such will endanger security and confidential restrictions that the government must protect. But in this particular case, the government itself allows the easy access to procurement information. The information regarding procurement in the subject institution is provided in Table 1, to wit;

Table 1 shows the summary of the data gathered during the interview with the respondents.

\begin{tabular}{|c|c|c|c|c|c|}
\hline $\begin{array}{l}\text { Bidding } \\
\text { Process }\end{array}$ & $\begin{array}{l}\text { Pre- } \\
\text { procurement }\end{array}$ & $\begin{array}{l}\text { Pre-Bid } \\
\text { Conference }\end{array}$ & Opening of Bids & $\begin{array}{l}\text { Post-Qua } \\
\text { Evaluation }\end{array}$ & Awards \\
\hline $\begin{array}{l}\text { Bidding } \\
\text { Activity }\end{array}$ & $\begin{array}{l}\text {-Evaluate } \\
\text { items to be bid } \\
\text { (price, specs, } \\
\text { warranty) } \\
\text {-Review the } \\
\text { content of } \\
\text { bidding } \\
\text { documents }\end{array}$ & $\begin{array}{l}\text {-Orient the } \\
\text { prospective bidders } \\
\text { on what to be bid } \\
\text { and highlight } \\
\text { important } \\
\text { requirements and } \\
\text { instruction regarding } \\
\text { to the bid proposal } \\
\text { they will submit. } \\
\text {-Entertain questions } \\
\text { of the bidders } \\
\text { regarding to the } \\
\text { public bidding } \\
\text {-Inform the supplier } \\
\text { of the submission } \\
\text { and deadlines }\end{array}$ & $\begin{array}{l}\text {-Open the eligibility } \\
\text { or technical } \\
\text { requirement of the } \\
\text { supplier. Only all } \\
\text { the bidder who pass } \\
\text { the eligibility } \\
\text { requirement will be } \\
\text { open the financial } \\
\text { proposal. Bidder } \\
\text { who failed can } \\
\text { submit motion for } \\
\text { reconsideration } 3 \\
\text { days after opening } \\
\text { of bids. Initial } \\
\text { evaluation will be } \\
\text { revealed to bidders. }\end{array}$ & $\begin{array}{l}\text {-Lowest bidder } \\
\text { will be the first } \\
\text { to be evaluated. } \\
\text { - Check the } \\
\text { validity } \\
\text { eligibility } \\
\text { requirements } \\
\text {-Review the bid } \\
\text { offer of the } \\
\text { supplier if it } \\
\text { matches with } \\
\text { the specification } \\
\text { indicated on the } \\
\text { bidding } \\
\text { documents }\end{array}$ & $\begin{array}{l}\text {-Prepare BAC } \\
\text { Resolution } \\
\text {-Prepare } \\
\text { Notice of } \\
\text { Award }\end{array}$ \\
\hline $\begin{array}{l}\text { Participants } \\
\text { of Bidding } \\
\text { Process }\end{array}$ & $\begin{array}{l}\text { End-user } \\
\text { TWG } \\
\text { BAC } \\
\text { Members } \\
\text { BAC } \\
\text { Secretariat } \\
\text { COA } \\
\text { Representative } \\
\text { Civil Society }\end{array}$ & $\begin{array}{l}\text { End-user } \\
\text { TWG } \\
\text { BAC Members } \\
\text { BAC Secretariat } \\
\text { Prospective Bidders } \\
\text { Participating } \\
\text { Bidders } \\
\text { COA Representative } \\
\text { Civil Society }\end{array}$ & $\begin{array}{l}\text { End-user } \\
\text { TWG } \\
\text { BAC Members } \\
\text { BAC Secretariat } \\
\text { Prospective Bidders } \\
\text { Participating } \\
\text { Bidders } \\
\text { COA } \\
\text { Representative } \\
\text { Civil Society }\end{array}$ & $\begin{array}{l}\text { End-user } \\
\text { TWG } \\
\text { BAC Members } \\
\text { BAC Secretariat } \\
\text { Participating } \\
\text { Bidders } \\
\text { COA } \\
\text { Representative } \\
\text { Civil Society }\end{array}$ & $\begin{array}{l}\text { End-user } \\
\text { TWG } \\
\text { BAC } \\
\text { Members } \\
\text { BAC } \\
\text { Secretariat } \\
\text { Participating } \\
\text { Bidders } \\
\text { COA } \\
\text { Representative } \\
\text { Civil Society }\end{array}$ \\
\hline $\begin{array}{l}\text { Documents } \\
\text { Available to } \\
\text { Public }\end{array}$ & $\begin{array}{l}\text { Annual } \\
\text { Procurement } \\
\text { Plan } \\
\text { Bid } \\
\text { Documents }\end{array}$ & $\begin{array}{l}\text { Invitation to Bid } \\
\text { Bidding Documents } \\
\text { Bid Bulletin } \\
\text { Minutes of Meeting } \\
\text { (Pre-Bid } \\
\text { Conference) }\end{array}$ & $\begin{array}{l}\text { Minutes of } \\
\text { Meetings } \\
\text { (Opening of Bids) }\end{array}$ & & $\begin{array}{l}\text { BAC } \\
\text { Resolution } \\
\text { Abstract of } \\
\text { Sealed Bids } \\
\text { Notice of } \\
\text { Awards } \\
\end{array}$ \\
\hline
\end{tabular}

3.1 Description of the observance of procedures on public bidding

According to the Respondents, there are five (5) major activities or process that is regularly practiced during the Public Bidding process. The first activity is the Pre-Procurement Conference. In this stage, the End-User, TWG, BAC Members and BAC Secretariat discuss the items to be procured, ensure that the items are included in the Annual Procurement Plan of the Institution, and confirm that, though without branding, the specifications are 
clearly stated. The cost per item are evaluated and guaranteed that it is not underestimate nor overestimate. The bidding documents are thoroughly reviewed, and the important notes or instructions to the bidders are clearly stated. The next activity is the Pre-Bid Conference. In this stage, all prospective bidders are allowed to attend the conference whether they have purchased the bidding document or not. The BAC Member as well as the TWG, End-user and BAC Secretariat will have a meeting with the prospective bidders to brief them about the conditions of public bidding; they give highlights on the important requirements and instructions in submitting their bid proposal, including the date and venue of submission. They also show the bidders all the items to be procured. Bidders, in this stage, may ask questions about the instruction of the bidding including questions with regards to the items to be bid. Bidders can also make suggestions for the betterment of the bidding process. After making things clear with the prospective bidders, the next activity to be conducted is the Opening of Bids. In this stage, only bidders who have purchased the bidding documents and submitted their bid proposals on the prescribed time and venue will be evaluated. Through a checklist of bid requirements, the eligibility and technical documents of the bidders will be evaluated. This will identify if the bidder is eligible to bid or not. Only bidders who passed the preliminary examination of eligibility documents can proceed with the opening of the financial documents which contain their bid price for the items. Disqualified bidders, on the other hand, are allowed to file for a Motion for Reconsideration within three (3) days after the bid opening. Their bid proposal will bear sealed in front of the attendees, signed by all the participating bidders and will be scheduled for reopening only if their MR was granted. After the opening of bids, the supplier with the lowest bid offer will be subjected to Post-Qualification Evaluation. In this stage, the TWG will verify the authenticity and validity of their eligibility documents and confirm their performance in the delivery of their previous contracts through their former clients or customers. If they passed the post-qualification stage, they will move on to the awarding stage. Transparency is strictly observed in the conduct of procurement activities such as in Public Bidding and ensured that the transactions are in accordance with the implementing rules and regulations of RA 9184.All bid opportunities that exceeded P50,000.00 are posted through the PhilGEPS, in the PhilRice website and in conspicuous places in the premises of the procuring entity. Uniformity in the forms for every transaction is also observed. The Property, Supply and Inventory System (PSIS), which is being used by the Institute, generates standard forms in making Procurement and Property Management Plan (PPMP), Stock, Plan and Budget Inquiry (SPBI), Purchase Request (PR), Purchase Order (PO), Inspection and Acceptance Report (IAR) and many more, which is linked to one another for easy tracking of records. And also their bid document is based on the form provided by the GPPB. Regular transmittal of documents to the Commission on Audit (COA) and the GPPB is also practiced for the purpose of check and balance.

All in all the Bids and Awards Committee of the agency under consideration observes the established rules in public bidding and procurement of goods and services as described during interview and field observation, the entity sees to it that the process is observed to prevent doubts on the part of the bidders and the public in general as to the manner the entity procures goods and services through pubic and competitive bidding. The importance of transparency and accountability in the procurement process is one way of demonstrating to the people the efficiency of the government. Cost-efficiency is the ratio between the minimum cost at which it is possible to attain a given volume of production and the cost actually incurred (Maudos et al., 1999). The full observance of public bidding procedures makes the procurement process easier, faster and transparent. Unnecessary delays are prevented due to reproduction or production of unsubmitted documents arising from non observance and digression from standard operating procedure on public bidding. The PhilRice observes the proper bidding process.

\subsection{Identify the entities who are allowed to participate in the public bidding process and their limitations during the process}

Shown in Table 1, is a list of participants who can join the bidding process. The following must be present in every stage of the bidding activity: end-user, members of the Technical Working Group (TWG) and BAC, BAC Secretariat, and the Observer which are representatives of COA and Civil Societies. They regularly send invitation to the observers five (5) days before the bidding activity. However, the presence of the supplier/s is only essential on Pre-Bid Conference, Opening of Bids, and Post-Qualification and on the time of awarding. Supplier's Forum is conducted every year to inform suppliers, who are mostly in the private sector; the updated rules and regulation stated in RA 9184(delete this part). They also give a glimpse of Annual Procurement Plan of the Institution on the upcoming year so that everyone will be aware for the future projects of the Institution. They also give suppliers the opportunity to showcase their products with the end-users for reference. In Public Bidding, the suppliers or contractors will be notified through their PhilGEPS registered e-mail once the BAC Secretariat received a bid proposal from them. Participating bidders are also informed of the outcome or results of the bidding. The procurement procedure in Philippine government goes electronic through PhilGEPS, to promote transparency and efficiency in the procurement system. It serves as the primary source of information on all government procurement. But according to Neu, Everret, \& Rahamann, (2015) the presence of e- 
procurement system may not totally control and surpass limitations on internal control and monitoring practices within corrupt contexts. However, the social media, such as Facebook, has not yet been used to communicate with suppliers in relation to the bidding activities of the institution. The presence of electronic resources to make public bidding as transparent as possible is a step towards increasing public accountability. However, this opportunity to engage in the public procurement process by ordinary citizens, through different media of communications depend to a great extant on the willingness of citizens to participate and serve as checking and balancing mechanism against corrupt activities (Bawan et al, 2018). The present of stakeholders in the bidding process not only makes it more transparent but also more accountable. Transparency is cultivated when many people are participating in a public activity. Transparency limits the opportunity for bribery and corruption. The use of digital technology also minimizes person to person contact and over the counter submission and sharing of information which greatly increase accountability while decreases corrupt opportunities. The agency is found to observe the presence of individuals in public bidding or procurement process, making it transparent and open to all interested citizens or members of Civil Society Organizations (CSOs).

\subsection{Public Access to Information and Data on the agency procurement activities}

Transparency enhances the access of the public to bidding documents. It is the "sunlight that disinfects the dark corridors of power of bureaucratic corruption", the more the documents in the bidding procedures open and accessible to the public, the lesser the opportunity of government officials to commit anomalous transaction for personal gain and advantage. Transparency discourages commission of unethical conduct because people who have access to the data available may monitor and demand observance of the procedure imposing pressure therefore on the government to remain objective in determining the appropriate private sector who would be awarded of the projects which government may establish. Based on the respondents, posting of Bid Opportunities in the PhilGEPS, in the PhilRice website, and in conspicuous places in the premises of the Procuring Entity is done if the Approved Budget for the Contracts (ABC) exceeded the amount of P50,000.00. Also, bid opportunities are being published in the newspaper (if the ABC exceeded $\mathrm{P} 10,000,000.00$ for Goods and Services, P15,000,000.00 for Infrastructure projects and P5, 000,000.00 for Consulting Services), and sent through e-mail addresses of prospective bidders. Supplier's Forum is conducted every year to inform suppliers, who are mostly in the private sector, the updated rules and regulation stated in RA 9184. They also give a glimpse of Annual Procurement Plan of the Institution on the upcoming year so that everyone will be aware for the future projects of the Institution. They also give suppliers the opportunity to showcase their products with the end-users for reference. The documents related to Public Bidding that are available to the public are the Annual Procurement Plan (APP), Bid Documents, Invitation to Bid, Bid Bulletin, Minutes of Meeting for Pre-Bid Conference, Minutes of Meeting for Opening of Bids, BAC Resolution, Abstract of Sealed Bids and Notice of Awards. Their APP, which consists of all the procurement activities of PhilRice is uploaded in their website as a part of their Transparency Seal. Invitation to Bids, Bid Documents, and Bid Bulletins are all posted on PhilGEPS website in compliance to RA 9184. And Minutes of Meetings, BAC Resolutions and other documents related to the public bidding can be acquired through request. It is also observed that participation of personnel including the invited observers from non government entities in the bidding process is in accordance to the requirement of the Public Procurement Act. During interview, some respondents narrated that some personnel believe that "palakasan" still holds at times. Indeed, stakeholders are encouraged to participate in the formulation of Annual Procurement Plan, as well as to observe the bidding process. According to Partnership for Transparency Fund (2013) the integration of public participation led to transparent, competitive, and accountable bidding processes in all government agencies. As a result of the project, citizens become more aware on the process of choosing the best bid prices during the procurement period which therefore contributes to better service delivery. The presence of Civil Society representatives is another feature of the public bidding process observed by the subject agency. The CSO's though few in number, discourages anomalies in public bidding. Documents of the agency proved that no bidding proceeding was allowed to push through without the presence of representatives of the CSO's. Though without voting power as to whom the bid amount should be given among bid competitors, the mere presence and being observers made them participants to the proceedings that would open wide the door of the government office for citizens participation and observance of transparency in the bidding activities. It is therefore shown that access and openness to public of pertinent information on public bidding is established. Interview result would point to the fact that the data and information are open and can be taken from the agency website and agency office in charge of bidding anytime during office hours.

\section{Conclusions}

Based on the data gathered through interviews and close observations, it can be noted that there is transparency in the procurement process conducted by the Philippine Rice Research Institute. Information regarding their bidding activities is accessible through the PhilGEPS and its official website and the attached files can easily be viewed or downloaded. They have a standard process in the implementation of their procurement activities since 
the Implementing Rules and Regulations of RA 9184 is strictly observed. In addition to this are the set of standard forms which is system-generated. The data tracking has been made easier and since it is system generated, they can ensure that all their procurement activities are included in their Project Procurement Management Plan.

It is recommended that active participation in the bidding process be encouraged by using social media or digital technology even of ordinary citizens not part of the procurement team and interested individuals. In this way intensification of transparency would further increase accountability and trust of the people in the community to the government entity doing the procurement activity. Cultivating, therefore, the governance principle that relationship between the people and the government is one that is built on trust and not a mere business contract.

\section{References}

Ballard Therese (2018). Transparency and public procurement. Accessed from https://www.ungm.org/Areas/Public/Downloads/ASR 2011 supplement.pdf; November 14, 2018

Bawan, O., Marcos, M. and Gabriel, A. (2017) E-Participation of Selected Professional Students in the Governance of Cabanatuan City in the Philippines. Open Journal of Social Sciences, 5, 126-139. doi: $10.4236 /$ jss.2017.512010.

Benito, (2016) Accountability and Corruption, Europe. In: Farazmand A. (eds) Global Encyclopedia of Public Administration, Public Policy, and Governance. Springer Cham

Bernas, JG, (1996) The 1987 constitution of the Republic of the Philippines: a commentary. Rex Bookstore, Manila; Google Scholar

Brillantes, A. B., \& Fernandez, M. T. F. T. (2011). Restoring trust and building integrity in government: Issues and concerns in the Philippines and areas for reform. International Public Management Review, 12(2), 5580 .

Competitive Bidding: What is Competitive Bidding? Accessed from https:/www.findrfp.com/GovernmentContracting/competitive-bidding.aspx; March 14, 2018.

Gabriel A.G. (2018) Bureaucratic Red Tape in the Philippines. In: Farazmand A. (eds) Global Encyclopedia of Public Administration, Public Policy, and Governance. Springer, Cham

Gabriel, G. Arneil (2017). Praxis In Local Legislative Governance: Measure Of Organizational Effectiveness of The Component Cities In Nueva Ecija, Philippines; Accessed from http://www.apjmr.com/wpcontent/uploads/2017/04/APJMR2017.5.2.02.pdf

Gabriel A.G. \& Ong Darwin U. (2018). Linking Transparency and Accountability to Local Legislative Performance in the Province of Nueva Ecija in the Philippines. Journal of Public Administration and Governance. 384-396. Vol. 8, No 2 (2018)

Ingrams A. (2016).Transparency. In: Farazmand A. (eds) Global Encyclopedia of Public Administration, Public Policy, and Governance. Springer, Cham

Maudos, J., Pastor, J.M., Pérez, F., \& Quesada, J. (1999). Cost and Profit Efficiency in European Banks. IVIE Working-papers

OECD (2014). Accountability and Democratic Governance: Orientations and Principles for Development, OECD Publishing, Paris, September 15, 2014. Retrieved from http://dx.doi.org/10.1787/9789264183636-en

Orelli, R.L., (2016).E-Government, Accountability, and Performance. In: Farazmand A. (eds) Global Encyclopedia of Public Administration, Public Policy, and Governance. Springer, Cham

Osborne, D. and Gaebler, T. (1992). Reinventing Government: How the Entrepreneurial Spirit is Transforming the Public Sector. Reading, Mass: Addison-Wesley.

Oei, A. (2005). Days of Thunder: How Lee Kuan Yew Blazed the Freedom Trail. Ti. Public Procurement Practice: Transparency in Public Procurement; Accessed from https://www.nigp.org/docs/defaultsource/New-Site/global-best-practices/transparency.pdf?sfvrsn=2; March 14, 2018

Republic Act 6713. (1989). Retrieved December 28, 2018, from https://www.lawphil.net/statutes/repacts/ra1989/ra_6713_1989.html

Republic Act No. 9184, The 2016 Revised Implementing Rules and Regulations Of Otherwise Known as The Government Procurement Reform Act of 2003.

Reyes, DR (1994). Reinventing government and bureaucracy in the Philippines: old themes and a new image? Philippine J Public AdmXXXVIII(2):77-97 Google Scholar von Lucke/Geiger 2010: von Lucke, J. \& Geiger, C. (2010). Open Government Data - Frei verfügbare Daten des öffentlichen Sektors, Gutachten für die Deutsche Telekom AG zur T - City Friedrichshafen, Version vom 03.12.2010, Deutsche Telekom Institute for Connected Cities, Zeppelin University, Friedrichshafen 2010. Retrieved November 26, 2012 , from http://www.zeppelin-university.de/deutsch/lehrstuehle/ticc/TICC-101203-OpenGovernmentDataV1.pdf.9999 